\title{
Lr72 Confers Resistance to Leaf Rust in Durum Wheat Cultivar Atil C2000
}

S. A. Herrera-Foessel, International Maize and Wheat Improvement Center (CIMMYT), Apdo. Postal 6-641, 06600 Mexico, D.F., Mexico; J. Huerta-Espino, Campo Experimental Valle de México INIFAP, Apdo. Postal 10, 56230, Chapingo, Edo de Mexico, Mexico; V. Calvo-Salazar, C. X. Lan, and R. P. Singh, International Maize and Wheat Improvement Center (CIMMYT), Apdo. Postal 6-641, 06600 Mexico, D.F., Mexico

\begin{abstract}
Herrera-Foessel, S. A., Huerta-Espino, J., Calvo-Salazar, V., Lan, C. X., and Singh, R. P. 2014. Lr72 confers resistance to leaf rust in durum wheat cultivar Atil C2000. Plant Dis. 98:631-635.

Leaf rust, caused by Puccinia triticina (Pt), has become a globally important disease for durum wheat (Triticum turgidum subsp. durum) since the detection of race group BBG/BN, which renders ineffective a widely deployed seedling resistance gene present in several popular cultivars including Mexican cultivars Altar C84 and Atil C2000. The resistance gene continues to play a key role in protecting durum wheat against bread wheat-predominant races since virulence among this race group has not been found. We developed $F_{3}$ and $F_{5}$ mapping populations from a cross between Atil C2000 and the susceptible line

using three $P t$ races. Segregation tests indicated the presence of a single gene, which was mapped to the distal end of 7BS by bulk segregant analysis. The closest marker, wmc606, was located $5.5 \mathrm{cM}$ proximal to the gene. No known leaf rust resistance genes are reported in this region; this gene was therefore designated as $L r 72$. The presence of $\operatorname{Lr} 72$ was further investigated in greenhouse tests in a collection of durum wheat using $13 P t$ races. It was concluded that at least one additional gene protects durum wheat from bread wheatpredominant $P t$ races.
\end{abstract} Atred \#1. Resistance was characterized by greenhouse seedling tests
Durum wheat (Triticum turgidum subsp. durum) is the second most important wheat cereal crop after bread wheat (T. aestivum). About half of the total durum wheat-producing area is located in developing countries, where it is used for making products such as pasta and couscous.

Leaf (brown) rust, caused by Puccinia triticina $(P t)$, is an important biotic constraint to wheat production. It has been controlled effectively by growing resistant cultivars, even though deployment of race-specific resistance genes associated with hypersensitive reactions has often led to "boom-and-bust" cycles, where cultivars with previously effective leaf rust resistance genes have succumbed to new, virulent races within a relatively short time. Most of the catalogued leaf rust resistance $(L r)$ genes are race-specific and have become ineffective to the predominant races in many regions $(10,15)$.

Historically, durum wheat was more resistant than bread wheat to leaf rust and rarely experienced leaf rust epidemics. The $P t$ populations present in durum wheat fields were known to be different from those occurring in bread wheat fields and were characterized by being avirulent on most of the catalogued $L r$ genes present in bread wheat $(9,19,23)$. However, the genetic basis of leaf rust resistance in durum wheat was not well studied, and only a few catalogued $L r$ genes were reported to originate or be present in the crop. It was not until a decade ago that leaf rust became a severe problem in durum wheat. In 2001, the exotic race BBG/BN was discovered in northwestern Mexico and was estimated to cause economic losses of around US\$32 million in Mexico during 2001 to 2003 (25). The unknown race-specific resistance gene that lost effectiveness had been widely deployed in Mexico for several years in numerous cultivars, including the most popular variety

\section{Corresponding author: S. A. Herrera-Foessel, E-mail: s.herrera@ cgiar.org}

* The $\boldsymbol{e}$-Xtra logo stands for "electronic extra" and indicates that a supplementary figure is available online.

Accepted for publication 20 November 2013.

http://dx.doi.org/10.1094/PDIS-07-13-0741-RE

(C) 2014 The American Phytopathological Society
'Altar C84'. In addition, this race was highly virulent on a majority of cultivars from 31 countries and on $80 \%$ of the durum wheat collection maintained at the International Maize and Wheat Improvement Center (CIMMYT) (25).

During the same period, many other countries such as France, Spain, Chile, and the United States (California) reported increased susceptibility of durum wheat to leaf rust. Ordonez and Kolmer $(19,20)$ found that durum wheat predominant isolates of $P t$ originating from most countries (except Ethiopia) had similar virulence phenotypes, suggesting a single common origin. Goyeau et al. (5) conducted extensive studies with French $P t$ isolates and showed that this group of races, including a race identical to $\mathrm{BBG} / \mathrm{BN}$, was already present in France in 1997.

After the detection of race $\mathrm{BBG} / \mathrm{BN}$ in 2001, progress was made in identifying new, effective sources of resistance to leaf rust in durum wheat. Some $L r$ genes known to be present in bread wheat, including $L r 14 a(6), L r 3 a(7)$, and $L r 27+L r 31$ (11), were also confirmed in durum wheat. While effective to BBG/BN, these mentioned genes are not effective to the predominant $P t$ races in bread wheat (14). Two additional resistance genes, known only in durum wheat, were also identified as effective to race BBG/BN: $L r 61$ in 'Guayacan INIA' and an undesignated gene in Camayo $(7,8)$.

Within a few years, $L r 27+\operatorname{Lr} 31, \operatorname{Lr} 3 a$, and $\operatorname{Lr} 61$ were rendered ineffective to durum wheat-specific races in Mexico (10-12). $\mathrm{BBG} / \mathrm{BN}$ evolved to gain virulence to $L r 27+L r 31$ in 2008 with detection of race $\mathrm{BBG} / \mathrm{BP}$ (11). Another variant of race $\mathrm{BBG} / \mathrm{BP}$, identified as $\mathrm{CBG} / \mathrm{BP}$, added virulence to $\operatorname{Lr3a}$ (12). In contrast, Lr61 succumbed to a variant of the old Mexican durum wheatspecific race BBB/BN, avirulent on Altar C84, in 2010 (J. HuertaEspino, unpublished).

In Mexico, LrCamayo and Lrl4a continue to be effective to durum wheat predominant leaf rust races, but virulence to $L r 14 a$ has been present in France since 2000 among races attacking durum wheat (5).

The fact that durum wheat varieties do not succumb to predominant bread wheat $P t$ races raises intriguing questions about the additional $L r$ gene (or genes) protecting durum wheat. While the $L r$ gene present in Altar C84 (and various other modern durum wheat varieties) became ineffective to the durum wheat-predominant $P t$ race group in 2001, the gene remains effective against races that commonly occur on bread wheat. There is therefore speculation 
that this gene (hereby named $L r 72$ ) continues to play a key role in protecting durum wheat germplasm from the leaf rust races that affect bread wheat.

The Mexican durum wheat variety 'Atil C2000', derived from Altar $\mathrm{C} 84$, was released one year before the appearance of race $\mathrm{BBG} / \mathrm{BN}$ in northwestern Mexico. It yielded about $10 \%$ more than Altar C84 and was rapidly adopted by durum wheat growers (25). Atil C2000 also carries $\operatorname{Lr} 72$ and became susceptible in 2001 when the $\mathrm{BBG} / \mathrm{BN}$ race emerged. This study aimed to: (i) characterize and map $L r 72$ using $\mathrm{F}_{3}$ and $\mathrm{F}_{5}$ populations developed from the cross of susceptible parent Atred \#1 with Atil C2000, and (ii) investigate the presence of $L r 72$ in a collection of durum wheat germplasm.

\section{Materials and Methods}

Plant materials. Atil C2000 (CIMMYT GID 6719128 with pedigree: Sooty_9/Rascon_37 = Altar 84/Sterna-DW_2/3/Altar 84/CMH82A.1062//Rissa) was selected as the parental source of resistance. The susceptible parent was Atred \#1 (CIMMYT GID 6719127), which was developed from a cross between Atil C2000 and the "universally" susceptible durum wheat land race "Local Red', and backcrossed to Atil C2000. Atred \#1 was specifically generated by J. Huerta-Espino (unpublished) to develop a universally susceptible durum wheat in an acceptable semi-dwarf agronomic background (Local Red is tall and susceptible to all known $P t$ races, including bread wheat-predominant races [9]). A total of 148 Atred \#1 × Atil C2000 $\mathrm{F}_{3}$ families were developed as a mapping population, which was derived from three $F_{1}$ plants and generated by individually harvested space-sown $\mathrm{F}_{2}$ plants that were treated with fungicide to avoid any bias caused by loss of suscepti- ble plants. The $\mathrm{F}_{3}$ population was further advanced for two generations by harvesting individual spikes, and a total of $132 \mathrm{~F}_{5}$ recombinant inbred lines (RILs) were developed to confirm the genomic position of $\operatorname{Lr} 72$.

An $\mathrm{F}_{2}$ population was also generated from a cross between Atil C2000 and Altar C84 (CIMMYT GID 30374) to confirm, through allelism, that the same gene conferred resistance in Altar C84. The Altar C84 $\times$ Atil C2000 $\mathrm{F}_{2}$ population was generated from four different $F_{1}$ plants. In order to investigate the presence of $L r 72$ in different durum wheat backgrounds, 11 CIMMYT lines known to carry different seedling $L r$ genes were included in a seedling greenhouse test (Table 1). A bread wheat leaf rust differential set of 48 entries, most of them in 'Thatcher' background, including bread wheat testers for $L r 3 a, L r 10, L r 14 a, L r 23$, and $L r 27+L r 31$, were also included as checks (Table 1).

Characterization of parents and populations in seedling tests. Two bread wheat-specific $P t$ races, $\mathrm{MBJ} / \mathrm{SP}$ and TCB/TD, were selected for the characterization of $L r 72$ in the greenhouse using the $\mathrm{F}_{3}$ population. The avirulence/virulence patterns of the two races are given below, with genes with partial virulence/ avirulence described in brackets.

$\mathrm{MBJ} / \mathrm{SP}$ :

Lr2a,2b,2c,3ka,9,16,19,21,24,25,(26),28,29,30,32,33,36/1,3a,3bg, $10,11,12,13,14 a, 14 b, 15,17,18,20,23,27+31$

TCB/TD:

Lr3ka,9,10,11,16,17,19,21,24,25,27+31,29,30,32,33/1,2a,2b,2c,3a , $3 b g, 13,14 a, 14 b, 15,18,20,23,26,28$

For each race, approximately 30 to 40 seedlings of the parents and each $\mathrm{F}_{3}$ family were sown in plastic trays together with the leaf

Table 1. Seedling (two-leaf stage) infection-type responses for bread wheat and durum wheat testers and lines inoculated with 2 durum-specific and 11 bread wheat-specific Puccinia triticina races

\begin{tabular}{|c|c|c|c|c|c|c|c|c|c|c|c|c|c|c|}
\hline \multirow[b]{3}{*}{ Line } & \multirow[b]{3}{*}{$\operatorname{Lr}$ Gene(s) } & \multicolumn{13}{|c|}{ P. triticina races and infection types ${ }^{\mathrm{a}}$ at $16-28^{\circ} \mathrm{C}$} \\
\hline & & \multicolumn{2}{|c|}{$\begin{array}{l}\text { Durum-specific } \\
\text { races }\end{array}$} & \multicolumn{11}{|c|}{ Bread wheat-specific races } \\
\hline & & $\begin{array}{c}\text { BBG/ } \\
\text { BN }\end{array}$ & $\begin{array}{c}\mathrm{BBB}_{\mathrm{B}} \mathrm{BN}_{-} \\
\text {Lr61 Vir }\end{array}$ & $\begin{array}{c}\text { MFB/ } \\
\text { SP }\end{array}$ & $\begin{array}{c}\text { CCJ/ } \\
\text { SP }\end{array}$ & $\begin{array}{l}\text { CBJ/ } \\
\text { QB }\end{array}$ & $\begin{array}{l}\text { CBJ/ } \\
\text { QQ }\end{array}$ & $\begin{array}{c}\text { MLJ/ } \\
\text { SP }\end{array}$ & $\begin{array}{c}\text { TCB } / \\
\text { TD }\end{array}$ & $\begin{array}{c}\text { LCJ/ } \\
\text { BN }\end{array}$ & $\begin{array}{c}\text { MBJ/ } \\
\text { SP }\end{array}$ & $\begin{array}{l}\text { TBD/ } \\
\text { TM }\end{array}$ & $\begin{array}{c}\text { MCJ/ } \\
\text { QM }\end{array}$ & $\underset{\text { SP }}{\text { MCJ/ }}$ \\
\hline \multicolumn{15}{|c|}{ Bread wheat } \\
\hline Thatcher & $L r 22 b^{\mathrm{b}}$ & $3+$ & $3+$ & $3+$ & $3+$ & $3+$ & $3+$ & $3+$ & 4 & $3+$ & 3 & $3+$ & 3 & $3+$ \\
\hline RL6004 & $\operatorname{Lr} 10^{\mathrm{c}}$ & 3 & $3+$ & $3+$ & $3+$ & $; 1$ & $3+$ & $3+$ & ;1 & $3+$ & 3 & $3+$ & $3+$ & 4 \\
\hline RL6002 & $L r 3 a^{\mathrm{c}}$ & $; 1-$ & $\mathrm{X}+3$ & $3+$ & $3+$ & $3+$ & 3 & $3+$ & 4 & $; 1-$ & 3 & $3+$ & $3+$ & 3 \\
\hline RL6013 & $L r 14 a^{\mathrm{c}}$ & $\mathrm{X}$ & $\mathrm{X}$ & $3+$ & $3+$ & $3+$ & $3+$ & 4 & $3+$ & 4 & 3 & $3+$ & $3+$ & 4 \\
\hline Gatcher & $\operatorname{Lr} 10, \operatorname{Lr} 27+\operatorname{Lr} 31$ & ; & ; & 3 & $\mathrm{X}+$ & ;1- & $\mathrm{X}$ & $3+$ & ; & $; 1$ & 3 & 4 & $3+$ & 3 \\
\hline RL6012 & $\operatorname{Lr} 23^{\mathrm{c}}$ & 3 & $3+$ & $3+$ & $3+$ & $1-$ & 1 & $2+$ & 4 & $3+$ & 3 & $2+3 \mathrm{C}$ & 1 & 4 \\
\hline Gaza & $\operatorname{Lr} 10,23,+$ & $\mathrm{X}$ & $3+$ & $3+$ & $3+$ & $; 1$ & $3+$ & $3+$ & $; 1$ & $3+$ & 3 & $3+$ & $3+$ & 4 \\
\hline Baviacora & $\operatorname{Lr} 14 b, L r 27+\operatorname{Lr} 31$ & $; 12$ & $; 1-$ & 12 & $\mathrm{X}+$ & $\mathrm{X}$ & $\mathrm{X}$ & $2+3$ & $X_{-}$ & $\mathrm{X}$ & $3+$ & $3+$ & $3+$ & $3+$ \\
\hline RL6079 & $\operatorname{Lr} 28^{\mathrm{c}}$ & $; 1$ & $3+$ & $3+$ & 0 & 0 & 0 & 4 & $3+$ & $3+$ & 0 & $3+$ & 0 & 0 \\
\hline \multicolumn{15}{|c|}{ Durum wheat } \\
\hline Local red & Susceptible & $3+$ & $3+$ & 4 & 4 & 4 & 4 & 4 & $3+$ & 4 & 4 & $3+$ & 4 & 4 \\
\hline Atred \#1 & Susceptible & $3+$ & $3+$ & $3+$ & $3+$ & $3+$ & $3+$ & $3+$ & $3+$ & $3+$ & $3+$ & $3+$ & $3+$ & $3+$ \\
\hline Atil C2000 & $\operatorname{Lr} 72$ & $3+$ & 1 & $; 1-$ & $; 1-$ & 0 & ; & $; 1-$ & $; 1$ & $; 1$ & $; 1$ & ; & ; & $; 1-$ \\
\hline Altar 84 & $\operatorname{Lr} 72$ & $3+$ & 1 & ; & ; & ; & ; & $; 1$ & $; 1$ & 1 & ; & ; & ; & $; 1$ \\
\hline $\begin{array}{l}\text { Jupare } \\
\text { C2004 }\end{array}$ & $\operatorname{Lr} 27+\operatorname{Lr} 31, \operatorname{Lr} 72$ & $\mathrm{X}$ & $; 12-$ & $; 1-$ & $; 1-$ & $; 1-$ & 1 & $; 1$ & $; 1-$ & $; 1$ & $; 1-$ & $; 1-$ & $; 1$ & $; 1-$ \\
\hline $\begin{array}{l}\text { Llareta } \\
\text { INIA }\end{array}$ & Lr14a,Lr72 & $X$ & $; 1$ & $; 1-$ & $; 1$ & $; 1-$ & $; 1-$ & $; 1-$ & $; 1-$ & 1 & $; 1-$ & $; 1-$ & 1 & 1 \\
\hline Somateria & Lr14a,+ & $\mathrm{X}+$ & ; & $; 1$ & $\mathrm{X}$ & $; 1-$ & $; 1-$ & $1+$ & 12 & $2+3 \mathrm{C}$ & $23 \mathrm{C}$ & 12 & $; 1-$ & $\mathrm{X}+3$ \\
\hline Camayo & LrCamayo & $; 1-$ & ; & ; & ; & 0 & 0 & ; & ; & $; 1-$ & ; & ; & ; & ; \\
\hline Storlom & Lr3a,Lr72 & 0 & ; & $; 1-$ & $; 1-$ & 0 & ; & $; 1-$ & ;1- & 0 & ;1- & $; 1-$ & ; & $; 1-$ \\
\hline Guayacan 2 & Lr61 & $; 1$ & $3+$ & ;1- & $; 1-$ & $; 1-$ & $\mathrm{X}+$ & ;1- & ; & 1 & 12 & ;1- & $1+3 \mathrm{C}$ & 12 \\
\hline $\begin{array}{l}\text { Guayacan } \\
\text { INIA }\end{array}$ & Lr61 & $; 1$ & $3+$ & $; 1-$ & 1 & $; 1-$ & $1+3 \mathrm{C}$ & $; 1-$ & $; 1$ & 1 & 12 & $; 1-$ & $1+$ & $; 1$ \\
\hline DW7276 & & $3+$ & $3+$ & 1 & 12 & 12 & $1+$ & 1 & $1+$ & 1 & 12 & 12 & 1 & 12 \\
\hline
\end{tabular}

a Infection types are based on a 0 to 4 scale (22), where ' 0 ' = no uredinia or other macroscopic signs of infection; ';' = no uredinia, but with hypersensitive necrotic or chlorotic flecks of varying sizes; ' 1 ' = small uredinia surrounded by necrosis; ' 2 ' = small to medium uredinia surrounded by green islands; ' $\mathrm{X}$ ' $=$ random distribution of variable-sized uredinia on a single leaf with a pure culture; ' 3 ' and ' 4 ' = medium and large uredinia, respectively, without chlorosis or necrosis; ' + ' and '- or $=$ ' = uredinia somewhat larger and smaller, respectively, than normal for the standard infection type; 'C' = more chlorosis than normal for the infection-type. More than one designation represents a range of infection types on the same plant.

${ }^{\mathrm{b}} \mathrm{Lr} 22 b$ is an adult plant resistance gene, but adult plants of Thatcher are susceptible to all races used here.

${ }^{c}$ Genes in Thatcher background. 
rust differential set. Plants were inoculated at the two-leaf stage by spraying urediniospores suspended in the light mineral oil Soltrol 170 (Chempoint.com). After $18 \mathrm{~h}$ of dew exposure in darkness, plants were transferred to a greenhouse maintained at 16 to $28^{\circ} \mathrm{C}$ with 16-h light period. At 10 days postinoculation, we evaluated plants for infection type responses according to a 0 to 4 scale (22), where ' 0 ' = no uredinia or other macroscopic signs of infection; ';' $=$ no uredinia, but with hypersensitive necrotic or chlorotic flecks of varying sizes; ' 1 ' = small uredinia surrounded by necrosis; ' 2 ' = small to medium uredinia surrounded by green islands; ' $X$ ' $=$ random distribution of variable-sized uredinia on a single leaf with a pure culture; ' 3 ' and ' 4 ' = medium and large uredinia, respectively, without chlorosis or necrosis; ' + ' and ' - or =' = uredinia somewhat larger and smaller, respectively, than normal for the standard infection type classification; ' $\mathrm{C}$ ' = more chlorosis than normal for the infection-type classification. More than one designation represents a range of infection types on the same plant. Plants with infection types ' 3 ' and ' 4 ' were considered susceptible; whereas those with other infection types were considered resistant. Each family was categorized as homozygous resistant (all plants resistant), homozygous susceptible (all plants susceptible), or segregating (families with both susceptible and resistant plants originating from a heterozygous $\mathrm{F}_{2}$ plant), depending on the within-family infection type responses.

For the allelism test between Altar C84 and Atil C2000, a total of $800 \mathrm{~F}_{2}$ plants were evaluated under two different greenhouse conditions at the seedling stage with the original Mexican durumspecific $P t$ race BBB/BN avirulent on $\operatorname{Lr} 72(23,25)$. We used the same procedure as described above.

The durum-specific $P t$ race $\mathrm{BBB} / \mathrm{BN} \_$Lr61Vir, identified in 2010, was used to characterize $L r 72$ using the $F_{5}$ Atred \#1 $\times$ Atil C2000 RILs. The virulence pattern of this race, similar to BBB/BN (23) but with additional virulence on $L r 61$, is the following: $L r l$, $2 a, 2 b, 2 c,(3), 3 b g, 3 k a, 9,11,13,14 a, 15,16,17,18,19,21,24$, 25, (26), 27+31,30,32/10,23,28,33,61. The methods described for the $\mathrm{F}_{3}$ population were also used for the $\mathrm{F}_{5}$ RILs, except that a data logger (LogTag analyzer, ver. 1.9) was programmed to measure the postinoculation temperature every $30 \mathrm{~min}$. The minimum, maximum, and average temperatures in the greenhouse were 4, 38, and $15^{\circ} \mathrm{C}$, respectively.

A total of $26 \mathrm{~F}_{5}$ RILs, including potential recombinants between marker and gene, were reevaluated in an additional greenhouse test to confirm the presence of $L r 72$. Two Pt races, BBB/BN_Lr61Vir and $\mathrm{MBJ} / \mathrm{SP}$, were used for confirmation. The minimum, maximum, and average postinoculation temperatures were 11,35 , and $19^{\circ} \mathrm{C}$, respectively.

Comparison of seedling infection type responses of $\mathrm{Lr} 72$ with a durum set. In order to investigate the presence of $L r 72$ in a collection of durum wheat lines, we conducted greenhouse experiments with an array of 11 Mexican bread wheat-specific and two durum-specific $P t$ races (BBG/BN and BBB/BN_Lr61Vir). The avirulence/virulence pattern of BBG/BN is: $L r l, 2 a, 2 b, 2 c, 3 a, 3 b g$, $3 \mathrm{ka}, 9,13,14 a, 15,16,17,18,19,21,24,25,26,27+31,28,29,30,32,36 / 10$, $11,14 b, 20,23,33$. We used bread wheat-specific races belonging to two major Mexican $P t$ race groups: one group was detected in Mexico before 1994 and includes TBD/TM and TCB/TD; the other group includes $\mathrm{MCJ} / \mathrm{SP}$ and $\mathrm{MBJ} / \mathrm{SP}$. The second $P t$ group was introduced to Mexico after 1994 and now predominates in bread wheat fields (10).

The seedling test included the susceptible checks Local Red and Atred \#1 and a collection of durum wheat lines with previously characterized $L r$ genes (Table 1). These included 'Jupare C2001' with $L r 27+L r 31$ (11); 'Somateria' and 'Llareta INIA' with Lr14a (6); 'Storlom' with Lr3a; Camayo with LrCamayo, a gene linked in repulsion or allelic to $\operatorname{Lr3a}(7)$; Guayacan INIA and 'Guayacan 2' with $\operatorname{Lr61}$ (8); and an additional durum, 'DW7276', previously used in a study by Singh et al. (24) as a seedling susceptible parent for investigating the genetic bases of resistance in nine durum wheat genotypes, including Altar C84 with $P t$ race $\mathrm{BBB} / \mathrm{BN}$. The infection types of susceptible check Thatcher and differentials for
$L r 3 a, L r 10, L r 14 a, L r 23, L r 27+L r 31$, and $L r 28$ in Thatcher or another bread wheat background are given in Table 1. Inoculation and evaluation methods were similar to those described earlier, and a greenhouse temperature range of 16 to $28^{\circ} \mathrm{C}$ was used for incubation.

Molecular marker analysis. Twenty plants from each $\mathrm{F}_{3}$ family of the Atred \#1 × Atil C2000 population were grown in the greenhouse, together with the parents. Leaf tissues were harvested and lyophilized approximately 3 weeks after sowing. DNA extraction was carried out according to a cetyltrimethylammonium bromide (CTAB) procedure described in CIMMYT protocols (4). A bulked segregant analysis approach, initially described by Michelmore et al. (16), was used for mapping $L r 72$. Equal amounts of DNA from six homozygous resistant families and six homozygous susceptible families were used for each bulk. More than 500 widely distributed simple sequence repeat (SSR) markers were screened on the parents and resistant and susceptible bulks. This collection included a list of markers recommended by Somers et al. (27). Polymorphic SSR markers were screened across the entire population. GrainGenes 2.0 (http://wheat.pw.usda.gov/GG2/index. shtml) was used to identify additional SSR markers in the region where $\operatorname{Lr} 72$ was initially mapped. Polymerase chain reactions were performed according to standard protocols (4); the products were separated in $10 \%$ acrylamide $(29: 1)$ gels, and bands were visualized by silver staining.

Linkage and statistical analysis. We used the chi-squared $\left(\chi^{2}\right)$ test excel function for goodness-of-fit to compare the observed segregation ratio of $F_{3}$ and $F_{5}$ lines for seedling responses with expected ratios, to determine the number of segregating resistance genes. ICImapping 3.3 (http://www.isbreeding.net) was used to develop linkage maps with a minimum $3.0 \mathrm{log}$ of odds (LOD) score for the linkage analyses. MAP distances were calculated using the Kosambi mapping function, and marker ordering was validated by three different ordering algorithms (Seriation, Record, and Multi Fragment). The rippling command was used to validate the order of the markers in the linkage map, which was drawn using MapChart (28).

\section{Results}

Leaf rust reactions of parents and Atred \#1 $\times$ Atil $\mathbf{C 2 0 0 0}$ populations. In the greenhouse at seedling stage, Atred \#1 displayed infection type ' $3+$ ' and Atil C2000 showed infection types ';12-' and ';' with $P t$ races MBJ/SP and TCB/TD, respectively. Similar infection types were obtained with race BBB/BN_Lr61Vir ('3+' versus '12'; Supplementary Figure $\mathrm{S} 1$ ). The $\mathrm{F}_{3}$ families of Atred \#1 × Atil C2000 were scored as homozygous resistant, segregating, or homozygous susceptible. Responses of $F_{3}$ families were identical to races MBJ/SP and TCB/TD, with a distribution of 36 homozygous resistant: 76 segregating : 36 homozygous susceptible $\left(\chi_{1: 2: 1}^{2}=0.11 ; P_{2 \mathrm{df}}=0.95\right)$ in accordance with segregation of a single gene. The evaluation of $\mathrm{F}_{5}$ RILs with $P t$ race $\mathrm{BBB} / \mathrm{BN} \_$Lr61Vir confirmed the $\mathrm{F}_{3}$ results with phenotypic distribution of 58 homozygous resistant: 12 segregating: 62 homozygous susceptible $\left(\chi_{1: 2: 1}^{2}=1.54 ; P_{2 \mathrm{df}}=0.46\right)$.

Test of allelism between Atil C2000 and Altar C84. Allelism tests conducted with $P t$ race BBB/BN confirmed that Atil C2000 and Altar C84 carry the same resistance gene because no susceptible plant was found among the $800 \mathrm{~F}_{2}$ plants evaluated. A range of infection type of ' 0 ;' to ' $11+$ ' was recorded in the allelism test population. Plants with the highest infection type were harvested for progeny testing with the same $P t$ race and confirmed to be resistant.

Molecular mapping of $\mathbf{L r} \mathbf{7 2}$. The close genetic relationship between the parents Atred \#1 and Atil C2000 resulted in few polymorphic markers. Bulked-segregant analysis and subsequent saturation with markers in the targeted region identified three SSR markers associated with the resistance locus. The three markers were located at the distal end of chromosome arm 7BS; the closest marker, wmc606, was located $5.0 \mathrm{cM}$ proximal to the gene, based on results for $148 \mathrm{~F}_{3}$ families. The marker wmc606 was co-domi- 
nant, and most of the genotypes heterozygous for $\operatorname{Lr} 72$ in the $\mathrm{F}_{3}$ population could be predicted by using the marker. Two markers, barc 279 and $g w m 537$, were located more proximal to the centromere at distances of 12.3 and $23.1 \mathrm{cM}$, respectively. The $\mathrm{F}_{5}$ RILs confirmed the distal position of $\operatorname{Lr72}$; wmc606 was located at 5.5 $\mathrm{cM}$, but advanced levels of homozygosity in the population allowed for better mapping resolution of barc279 and gwm537, which were estimated at 7.0 and $17.9 \mathrm{cM}$, respectively (Fig. 1).

Comparison of infection types displayed by $\mathrm{Lr} 72$ and the durum wheat collection. The susceptible checks Local Red and Atred \#1 displayed susceptible reactions to all races used in the study (Table 1). The infection types displayed by Atil C2000 and Altar C84 were similar: resistant to the 11 bread wheat-specific races and durum-specific race $\mathrm{BBB} / \mathrm{BN} \_$Lr61Vir, and susceptible to the durum-specific race BBG/BN. Jupare C2001, Llareta INIA, Camayo, and Storlom had similar infection types to the bread wheat-specific races and were also resistant to the two durumspecific races due to the presence of either $L r 27+L r 31, L r 14 a$, LrCamayo, or Lr3a (Table 1). Jupare C2001, Llareta INIA, and Storlom were postulated to carry $\operatorname{Lr} 72$ because they remained resistant and showed similar infection types as Atil C2000 and Altar C84 against bread wheat-specific races that are virulent on $\operatorname{Lr} 3 a$, $L r 14 a$, and $L r 27+L r 31$. The resistance gene in Camayo was effective against all races with very low infection type, and therefore the presence of $L r 72$ could not be postulated. Somateria displayed intermediate levels of resistance to various $L r 14 a$-virulent bread wheat-specific races, compared to the lower infection types associated with $L r 72$. This indicates the presence of an unidentified

\section{BS}

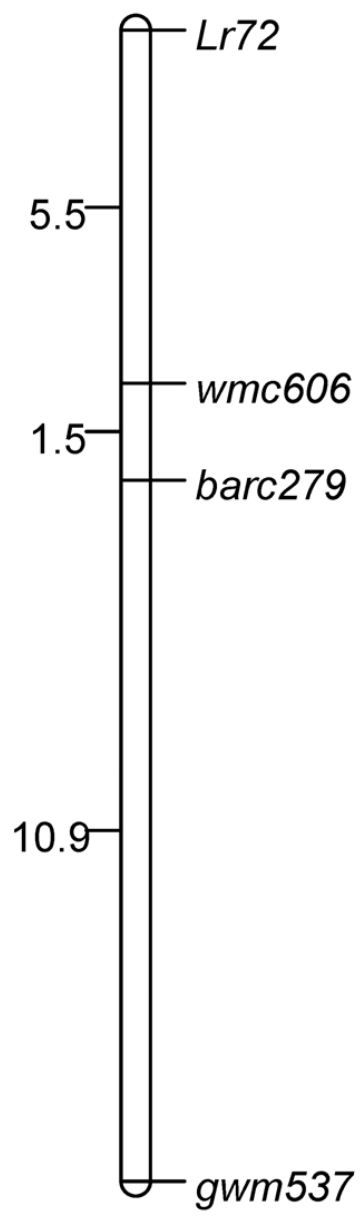

Fig. 1. Genetic map of leaf rust resistance gene $L r 72$ based on $132 \mathrm{~F}_{5}$ recombinant inbred lines from the cross Atred \#1 × Atil C2000. resistance gene in Somateria, in addition to Lr14a. Guayacan INIA and Guayacan 2 were resistant to all races except BBB/BN_Lr61Vir, a race virulent to $L r 61$ and avirulent to $L r 72$, indicating the absence of $\operatorname{Lr} 72$ in these durum wheat varieties. Hence, these two lines are most likely only protected by Lr61 against bread wheat-specific races. DW7276 was susceptible to both durum-specific races, but was resistant to bread wheatspecific races, indicating that it carries a gene different from $L r 72$.

\section{Discussion}

In this study, $\operatorname{Lr} 72$, a leaf rust resistance gene widely deployed in durum wheat was mapped to chromosome arm $7 \mathrm{BS}$ using $\mathrm{F}_{3}$ and $\mathrm{F}_{5}$ populations from the cross Atred \#1 $\times$ Atil C2000. The gene can be traced to Altar C84 or 'Gallareta' (CIMMYT name given in 1982), which has the pedigree Ruff/Flamingo-DR//Mexicali C75/3/Shearwater. $\operatorname{Lr} 72$ remained effective for 16 years before it was overcome in Mexico by the $P t$ race BBG/BN in 2001 (25). The original source of $\operatorname{Lr} 72$ in Atil C2000 and Altar C84 is unknown. Altar C84 and its derivatives were widely adopted under different names in Europe, the Middle East, and North Africa. Goyeau et al. (5) postulated that the French varieties 'Biensur', 'Dakter', and 'Orlu' have the same $L r$ gene(s) as Altar C84. Virulence on Altar C84 was reported in France in 1997, i.e., before the release of Biensur in 2001. Park et al. (21) suggested that isolates identified in 1995 in southern France, which were highly virulent on durum wheat varieties, could have originated from North Africa due to similar pathogenicity and marker profiles with a Moroccan isolate, but the reverse could also be true.

By extensive association analysis on a collection of durum wheat lines, Maccaferri et al. (13) identified a similar region in chromosome 7BS, which was associated with seedling resistance to different $P t$ races (both durum- and bread-wheat specific), as well as adult plant resistance, based on artificially induced leaf rust epidemics in field experiments conducted in Italy and Mexico. The association found in the same region based on the Mexican field data must have been due to a different gene, or due to combinations involving $L r 72$, because the $P t$ races used in their study were virulent to $\operatorname{Lr} 72$.

The presence of $L r 72$ in bread wheat must be rare since no catalogued $L r$ gene has been mapped to the same region. The "synthetic" hexaploid parent of the ITMI reference mapping population was originally thought to have been developed from Altar C84. This gene was at first thought to be suppressed in the synthetic and RILs, since the synthetic and RILs were susceptible to some of the bread wheat-specific races $(2,17,26)$. However, this needs further confirmation because Singh et al. (26) found evidence based on stripe rust seedling data that Altar C84 was not the true parent of the synthetic. Furthermore, two studies using different populations derived from the synthetic hexaploid identified $\operatorname{Lr} 23$ (17) and $\operatorname{Lr} 10$ (1) in Altar C84 but did not report the presence of any additional gene.

Singh et al. (24) investigated the genetic basis of leaf rust resistance in Altar C84 and eight additional durum wheats using $P t$ race $\mathrm{BBB} / \mathrm{BN}$. Populations were developed from crosses with seedling susceptible DW7276 and 'Iumillo'. The same single, partially dominant gene giving infection type ' 12 ' to race $\mathrm{BBB} / \mathrm{BN}$ was found to confer seedling resistance in Altar C84, 'Carcomun', 'Morus', and 'Totanus'. This gene did not confer adequate levels of adult plant resistance (up to $60 \%$ severity was recorded in some of the progenies), and it was found to interact with an additional adult plant resistance gene in the field. In our study, the susceptible parent DW7276 showed infection type ' 1 ' to ' 12 ' for all the bread wheat-specific races and was susceptible to race $\mathrm{BBG} / \mathrm{BN}$ and the related race $\mathrm{BBB} / \mathrm{BN}$ virulent on $\operatorname{Lr61}\left(\mathrm{BBB} / \mathrm{BN} \_L r 61\right.$ Vir). DW7276 must carry a gene (other than $L r 72$ ) that is effective against bread wheat-specific races, because it was susceptible to $\mathrm{BBB} / \mathrm{BN} \_L r 61$ Vir, to which $L r 72$ is effective. This gene is also different from $L r 61$ since DW7276 is susceptible to BBG/BN, to which $\operatorname{Lr61}$ is effective.

Based on the responses of DW7276, Guayacan INIA, and Guayacan 2, it can be concluded that at least one additional gene, 
other than $L r 72$, protects durum wheat varieties from bread wheatspecific races. A marker diagnostic for $L r 72$ would be useful to investigate its presence in durum wheat germplasm. The linked marker wmc606 was tested in a collection of 120 durum wheat lines, including some bread wheat checks, but was not useful in predicting $L r 72$ in different genetic backgrounds (results not shown). Progress is being made in identifying a more closely linked marker that could be used diagnostically to track the gene in diverse germplasm. The recent sequencing of chromosome 7BS (3) could assist with fine mapping and development of a useful marker for $\operatorname{Lr} 72$. The 7BS region involves a rearrangement with chromosome 4AL $(3,18)$, and detailed resolution is now available for this previously reported translocation from which an evolutionary perspective could provide insight on the origin of $L r 72$. Berkman et al. (3) found that approximately $13 \%$ of genes from $7 \mathrm{BS}$ were translocated to $4 \mathrm{AL}$, and an additional 13 genes found on 7BS appear to have originated from $4 \mathrm{AL}$.

The mechanism that protects durum wheat from Pt races common on bread wheat, and vice versa, is most likely the presence of different resistance genes in the two species, genes that the pathogen may overcome in the future. The durum-specific race BBG/BP was recently found to be virulent on 'Tacupeto F2001', a Mexican bread wheat cultivar. This was the first time that a durum-specific race was observed to attack a commercial Mexican bread wheat cultivar grown in the same region at the same time. Tacupeto F2001 is known to be slow rusting, so leaf rust severities in the field remain low compared to those of adjacent durum wheat fields, but it can serve as a source of inoculum for further mutation and selection of virulence in BBG/BP to overcome the resistance genes LrI4a and LrCamayo currently deployed in popular durum wheat cultivars. An ongoing search for slow rusting minor gene resistance in durum wheat is essential for ensuring future protection from leaf rust.

\section{Acknowledgments}

We appreciate the financial support from GRDC and CIMMYT, SAGARPACONACYT of Mexico (Fondo Sectorial project 146788). We also thank R. A. McIntosh and E. Quilligan for the technical editing.

\section{Literature Cited}

1. Aguilar Rincon, V., Singh, R., Castillo Gonzalez, F., and Huerta-Espino, J. 2001. Genes of leaf rust resistance in a synthetic hexaploid wheat. Rev. Fitotec. Mex. 24:161-169.

2. Aguilar Rincon, V., Singh, R., and Molina Galan, J. 1999. Genetics of leaf rust resistance in four synthetic hexaploid wheats. Rev. Fitotec. Mex. 22:215-226.

3. Berkman, P. J., Skarshewski, A., Manoli, S., Lorenc, M. T., Stiller, J., Smits, L., Lai, K., Campbell, E., Kubalakova, M., Simkova, H., Batley, J., Dolezel, J., Hernandez, P., and Edwards, D. 2012. Sequencing wheat chromosome arm 7BS delimits the 7BS/4AL translocation and reveals homoeologous gene conservation. Theor. Appl. Genet. 124:423-432.

4. CIMMYT. 2005. Laboratory protocols: CIMMYT Applied Molecular Genetics Laboratory. 3rd ed. CIMMYT, Mexico, D.F.

5. Goyeau, H., Berder, J., Czerepak, C., Gautier, A., Lanen, C., and Lannou, C. 2011. Low diversity and fast evolution in the population of Puccinia triticina causing durum wheat leaf rust in France from 1999 to 2009, as revealed by an adapted differential set. Plant Pathol. 61:761-772.

6. Herrera-Foessel, S., Singh, R., Huerta-Espino, J., William, H., Garcia, V., Djurle, A., and Yuen, J. 2008. Identification and molecular characterization of leaf rust resistance gene $L r 14 a$ in durum wheat. Plant Dis. 92:469-473.
7. Herrera-Foessel, S., Singh, R. P., Huerta-Espino, J., William, H., Rosewarne, G., Djurle, A., and Yuen, J. 2007. Identification and mapping of Lr3a and a linked leaf rust resistance gene in durum wheat. Crop Sci. 47:14591466

8. Herrera-Foessel, S., Singh, R., Huerta-Espino, J., William, H. M., Rosewarne, G., Djurle, A., and Yuen, J. 2008. Molecular mapping of a leaf rust resistance gene on the short arm of chromosome $6 \mathrm{~B}$ of durum wheat. Plant Dis. 92:1650-1654.

9. Huerta-Espino, J., and Roelfs, A. 1992. Leaf rust on durum wheats. Vortr. Pflanzenzuchtg. 24:100-102.

10. Huerta-Espino, J., Singh, R. P., Germán, S., McCallum, B. D., Park, R. F., Chen, W. Q., Bhardwaj, S. C., and Goyeau, H. 2011. Global status of wheat leaf rust caused by Puccinia triticina. Euphytica 179:143-160.

11. Huerta-Espino, J., Singh, R., Herrera-Foessel, S., Perez-Lopez, J., and Figueroa-Lopez, P. 2009. First detection of virulence in Puccinia triticina to resistance genes $L r 27+L r 31$ present in durum wheat in Mexico. Plant Dis. 93:110.

12. Huerta-Espino, J., Singh, R., and Perez-Lopez, J. 2009. Phenotypic variation among leaf rust isolates from durum wheat in Northwestern Mexico. Page 29 in: Proc. 12th Int. Cereal Rusts Powdery Mildews Conf.

13. Maccaferri, M., Sanguineti, M. C., Mantovani, P., Demontis, A., Massi, A. Ammar, K., Kolmer, J. A., Czembor, J. H., Ezrati, S., and Tuberosa, R. 2010. Association mapping of leaf rust response in durum wheat. Mol. Breed. 26:189-228.

14. McIntosh, R., Wellings, C., and Park, R. 1995. Wheat rusts: An atlas of resistance genes. CSIRO, Australia.

15. McIntosh, R. A., Yamazaki, Y., Dubcovsky, J., Rogers, J., Morris, C., Somers, D. J., Appels, R., and Devos, K. M. 2012. Catalogue of Gene Symbols for Wheat: 2012. (Suppl.) http://www.shigen.nig.ac.jp/wheat komugi/genes/macgene/supplement2012.pdf

16. Michelmore, R., Paran, I., and Kesseli, V. 1991. Identification of markers linked to disease-resistance genes by bulked segregant analysis: A rapid method to detect markers in specific genomic regions by using segregating populations. Proc. Nat. Acad. Sci. USA 88:9828-9832.

17. Nelson, J., Singh, R., Autrique, J., and Sorrells, M. 1997. Mapping genes conferring and suppressing leaf rust resistance in wheat. Crop Sci. 37:19281935.

18. Nelson, J., Sorrells, M., Van Deynze, A., Hai Lu, Y., Atkinson, M., Bernard, M., Leroy, P., Faris, J. D., and Anderson, J. A. 1995. Molecular mapping of wheat: major genes and rearrangements in homoeologus groups 4,5,7. Genetics 141:721-731.

19. Ordoñez, M. E., and Kolmer, J. A. 2007. Virulence phenotypes of worldwide collection of Puccinia triticina from durum wheat. Phytopathology 97:344-351.

20. Ordoñez, M. E., and Kolmer, J. A. 2007. Simple sequence repeat diversity of a worldwide collection of Puccinia triticina from durum wheat. Phytopathology 97:574-583.

21. Park, R., Jahoor, A., and Felsenstein, F. 2000. Population structure of Puccinia recondita in Western Europe during 1995, as assessed by variability in pathogenicity and molecular markers. J. Phytopathol. 179: 169-179.

22. Roelfs, A., Singh, R., and Saari, E. 1992. Rust diseases of wheat: Concepts and methods of disease management. CIMMYT, Mexico, D.F.

23. Singh, R. 1991. Pathogenic variations of Puccinia recondita f. sp. tritici in wheat-growing areas of Mexico during 1988 and 1989. Plant Dis. 75:790-794.

24. Singh, R., Bechere, E., and Abdalla, O. 1993. Genetic analysis of resistance to leaf rust in nine durum wheats. Plant Dis. 77:460-463.

25. Singh, R. P., Huerta-Espino, J., Pfeiffer, W., and Figueroa-Lopez, P. 2004. Occurrence and impact of a new leaf rust race on durum wheat in Northwestern Mexico from 2001 to 2003. Plant Dis. 88:703-708.

26. Singh, R. P., Nelson, J. C., and Sorrells, M. E. 2000. Mapping Yr28 and other genes for resistance to stripe rust in wheat. Crop Sci. 40:1148-1155.

27. Somers, D. J., Banks, T., Depauw, R., Fox, S., Clarke, J., Pozniak, C., and McCartney, C. 2007. Genome-wide linkage disequilibrium analysis in bread wheat and durum wheat. Genome 50:557-567.

28. Voorrips, R. 2002. MapChart: Software for the graphical presentation of linkage maps and QTLs. J. Hered. 93:77-78. 